\title{
EKSISTENSI DAN MOTIVASI PRAMUWISATA LOKAL PEREMPUAN DI DAYA TARIK WISATA ALAS KEDATON
}

\author{
Gusti Ayu Putu Putri Indra Suari \\ Ni Gusti Ayu Susrami Dewi \\ Luh Gede Leli Kusuma Dewi \\ Email : gek.indras@gmail.com \\ PS. S1 Industri Perjalanan Wisata \\ Fakultas Pariwisata UNUD
}

\begin{abstract}
ABSTRAK
Keberadaan pramuwisata lokal yang seluruhnya berjenis kelamin perempuan menjadi keunikan tersendiri bagi Alas Kedaton sebagai suatu daya tarik wisata. Bertujuan untuk mengetahui eksistensi pramuwisata lokal perempuan di daya tarik wisata Alas Kedaton serta untuk mengetahui motivasi mereka bekerja sebagai pramuwisata lokal perempuan di daya tarik wisata Alas Kedaton. Jenis data yang digunakan adalah data kuantitatif dan kualitatif. Sedangkan sumber data yakni data primer dan sekunder. Data dikumpulkan melalui observasi, wawancara, kuesioner dan dokumentasi. Informan ditentukan secara purposive sampling. Terdapat 45 responden yang dipilih sebagai sampel dengan menggunakan metode simple random sampling. Dan teknik analisis data yang digunakan adalah analisis deskriptif kualitatif dan deskriptif kuantitatif.

Hasil menunjukkan bahwa eksistensi pramuwisata lokal perempuan di daya tarik wisata Alas Kedaton dari awal terbentuknya sampai saat ini dapat dikatakan masih eksis. Meskipun jumlah pramuwisata lokal perempuan di daya tarik wisata Alas Kedaton berkurang dibandingkan ketika awal terbentuknya. Sedangkan motivasi mereka bekerja sebagai pramuwisata lokal di daya tarik wisata Alas Kedaton adalah untuk memenuhi beberapa kebutuhan seperti physiological needs, safety and security needs, affiliation or acceptance needs, esteem needs, dan self actualization. Dan rata-rata responden menjawab motivasi mereka bekerja sebagai pramuwisata lokal perempuan di daya tarik wisata Alas Kedaton adalah untuk memenuhi kebutuhan afiliasi atau affiliation or acceptance needs.
\end{abstract}

Kata Kunci : Eksistensi, Motivasi, Pramuwisata, Perempuan, Daya Tarik Wisata Alas Kedaton.

\section{PENDAHULUAN}

Kabupaten Tabanan merupakan salah satu kabupaten di provinsi Bali yang memiliki beragam daya tarik wisata baik daya tarik wisata alam maupun daya tarik wisata budaya. Tercatat sejumlah 13 daya tarik wisata yang terdiri atas 6 daya tarik wisata alam yakni Bedugul, Kebun Raya Bedugul, Alas Kedaton, Air Panas Penatahan, Jatiluwih, dan Taman Kupu-Kupu serta 7 daya tarik wisata budaya yakni Tanah Lot, Ulun Danu Beratan, Candi Puputan Margarana, Puri Anyar Kerambitan, Puri Gede Kerambitan, Museum Subak, dan Pura Batukaru (Dinas Pariwisata Provinsi Bali, 2015).Salah satu daya tarik wisata khususnya daya tarik wisata alam yang terdapat di Kabupaten Tabanan adalah daya tarik wisata
Alas Kedaton. Alas Kedaton merupakan daya tarik wisata yang mengandalkan sumber daya alam sebagai daya tarik yakni berupa hutan, kera dan kelelawar. Selain itu, di tengah objek wisata Alas Kedaton terdapat pura yang disebut Pura Dalem Kahyangan Kedaton yang juga menjadi daya tarik di objek wisata ini. Pada daya tarik wisata Alas Kedaton terdapat pramuwisata lokal yang akan memandu sekaligus menjaga keamanan wisatawan dari kera-kera yang berkeliaran. Keunikan dari pramuwisata lokal ini yakni seluruhnya berjenis kelamin perempuan. Pramuwisata lokal perempuan ini tidak memungut bayaran saat memandu, namun di akhir tour wisatawan diarahkan ke artshop yang dimiliki untuk melihat atau membeli cinderamata yang ada di 
art shop tersebut. Berdasarkan observasi awal, diketahui bahwa dari pembelian cinderamata tersebut, para pramuwisata lokal perempuan memperoleh penghasilan. Pramuwisata lokal perempuan yang merupakan pemilik artshop memperoleh penghasilan dari keuntungan sepenuhnya pembelian cinderamata. Sedangkan pramuwisata lokal yang hanya sebagai pekerja di artshop memperoleh penghasilan $20 \%$ dari keuntungan pembelian cinderamata oleh wisatawan di artshop tempat mereka bekerja. Fenomena keberadaan pramuwisata lokal yang seluruhnya berjenis kelamin perempuan di daya tarik wisata Alas Kedaton, membuat penulis tertarik untuk mengetahui mengenai eksistensi pramuwisata lokal perempuan yang ada di daya tarik wisata Alas Kedaton mulai dari awal mula terbentuknya hingga keberadaannya sampai saat ini baik dari segi jumlah pramuwisata lokal perempuan dan aktivitas pemanduan wisatawan yang dilakukan oleh pramuwisata lokal perempuan serta mengenai motivasi mereka tetap bekerja sebagai pramuwisata lokal perempuan di daya tarik wisata Alas Kedaton.

\section{METODE PENELITIAN}

Adapun lokasi yang dipilih yakni di daya tarik wisata Alas Kedaton, Desa Kukuh, Kecamatan Marga, Kabupaten Tabanan, Bali. Definisi operasional variabel terdiri atas dua variabel yakni variabel eksistensi (Abidin, 2007 dalam Pardiana, 2015) dengan indikator : terbentuknya pramuwisata lokal perempuan di daya tarik wisata Alas Kedaton dan keberadaan pramuwisata lokal perempuan di daya tarik wisata Alas Kedaton dan variabel motivasi (Maslow dalam Hasibuan, 2015) dengan indikator : physiological needs, safety and security needs, affiliation or acceptance needs, esteem or status needs, dan self actualization.

Jenis data yang digunakan yakni data kuantitatif dan data kualitatif. Sumber data terdiri atas data primer dan data sekunder. Teknik yang digunakan untuk mengumpulkan data yakni observasi, wawancara, kuesioner, dan dokumentasi. Teknik penentuan informan secara purposive sampling. Teknik pengambilan dan penentuan sampel secara simple random sampling dan jumlah sampel yang digunakan yakni sejumlah 45 orang. Dimana jumlah sampel ini diperoleh melalui rumus Slovin. Teknik analisis data yang digunakan yakni teknik analisis deskriptif kualitatif dan deskriptif kuantitatif.

\section{HASIL DAN PEMBAHASAN}

Sejarah awal terbentuknya pramuwisata lokal perempuan di daya tarik wisata Alas Kedaton tidak terlepas dari keberadaan artshop-artshop di daya tarik wisata Alas Kedaton yang berjumlah 202 unit. Dikarenakan banyaknya jumlah artshop yang ada, mulai muncul permasalahan dalam hal ketidakmerataan dalam memperoleh pembeli. Oleh karena itu, diberlakukanlah sistem nomor antrean untuk seluruh artshop-artshop yang ada. Untuk menunggu giliran nomor antrian, setiap artshop wajib menunjuk satu orang perwakilan. Perwakilan inilah disebut sebagai pramuwisata lokal di daya tarik wisata Alas Kedaton. Jumlah pramuwisata lokal pun pada awalnya sesuai dengan jumlah kios artshop yakni berjumlah 202 orang baik perempuan maupun laki-laki.

Kini yang menggeluti profesi sebagai pramuwisata lokal di daya tarik wisata Alas Kedaton hanya kaum perempuan, dengan jumlah tercatat sebanyak 80 orang pramuwisata lokal perempuan. Dari 80 orang pramuwisata lokal perempuan yang ada di daya tarik wisata Alas Kedaton, sebanyak 45 orang digunakan sebagai responden.

Diperoleh data mengenai karakteristik responden yakni pramuwisata lokal perempuan yang ada di daya tarik wisata Alas Kedaton. Adapun dari 45 orang responden, frekuensi tertinggi yakni pada kelompok umur 30-39 tahun yakni sejumlah 22 orang atau Sebagian besar responden telah menempuh pendidikan Sekolah Menengah Atas (SMA) yakni sejumlah 25 orang atau sekitar $56 \%$ dari total responden. Responden yang telah bekerja sebagai pramuwisata lokal perempuan di daya tarik wisata Alas Kedaton selama 11-15 tahun menunjukkan jumlah yang paling banyak yakni sejumlah 15 orang atau sekitar 33\% dari total responden. Sebagian besar responden memiliki kisaran pendapatan rata-rata per bulan sebesar Rp.500.000-Rp.999.999 yakni sejumlah 36 orang atau setara dengan $80 \%$ dari total responden.

Sebagian besar jawaban responden mengenai motivasi mereka bekerja sebagai pramuwisata lokal perempuan di daya tarik wisata Alas Kedaton yakni pada pemenuhan kebutuhan akan afiliasi atau affiliation or acceptance needs dengan total skor 195 dan 
rata-rata skor sejumlah 4,3333 dengan kategori sangat setuju.

Eksistensi pramuwisata lokal perempuan di daya tarik wisata Alas Kedaton berawal dari sejarah awal terbentuknya pramuwisata lokal perempuan di daya tarik wisata Alas Kedaton tidak terlepas dari keberadaan 202 unit artshop yang ada di daya tarik wisata Alas Kedaton. Pada tahun 1988 mulai dibangun beberapa artshop di daya tarik wisata Alas Kedaton. Ketika itu, jumlah artshop yang ada \pm 30 unit. Seiring berjalannya waktu, jumlah artshop meningkat hingga berjumlah 202 unit. Dikarenakan banyaknya jumlah artshop, untuk mengatasi terjadinya ketidakmerataan dalam memperoleh pembeli, maka diberlakukan sistem nomor antrean. Dimana setiap artshop wajib menunjuk satu orang perwakilan untuk menunggu giliran nomor antrian tersebut. Perwakilan inilah disebut sebagai pramuwisata lokal di daya tarik wisata Alas Kedaton yang bertugas memandu sekaligus menjaga keamanan wisatawan yang berkunjung. Jumlah pramuwisata lokal pun sesuai dengan jumlah kios artshop yakni berjumlah 202 orang baik perempuan maupun laki-laki.

Penjelasan mengenai keberadaan pramuwisata lokal perempuan di daya tarik wisata Alas Kedaton sampai saat ini, diawali dengan gambaran pramuwisata lokal perempuan di daya tarik wisata Alas Kedaton itu sendiri. Pramuwisata lokal perempuan di daya tarik wisata Alas Kedaton merupakan pramuwisata lokal yang seluruhnya adalah perempuan yang bertugas untuk memandu wisatawan baik wisatawan domestik maupun wisatawan mancanegara berkeliling daya tarik wisata Alas Kedaton. Pramuwisata lokal perempuan di daya tarik wisata Alas Kedaton berpakaian seragam berwarna merah muda atau biru dengan kamen (kain) dan selendang serta membawa tongkat kayu untuk menjaga keamanan wisatawan yang dipandu. Terdapat suatu organisasi yang menaungi pramuwisata lokal perempuan yang ada di daya tarik wisata Alas Kedaton. Organisasi tersebut yakni Kelompok Pedagang Alas Kedaton. dalam melakukan kegiatan pemanduan wisatawan, pramuwisata lokal perempuan memiliki suatu tata tertib yang tercantum dalam AD/ART Kelompok Pedagang Alas Kedaton. Tata tertib tersebut antara lain terkait ketentuan dalam mengantar tamu, hak pramuwisata lokal perempuan, kewajiban pramuwisata lokal perempuan, larangan serta sanksi.
Karakteristik pramuwisata lokal perempuan di daya tarik wisata Alas Kedaton yang diperoleh dari sampel sebanyak 45 orang pramuwisata lokal perempuan, dari segi umur berkisar 30-39 tahun dengan status kawin serta paling banyak berpendidikan terakhir Sekolah Menengah Atas (SMA). Dominan pramuwisata lokal perempuan di daya tarik wisata Alas Kedaton telah bekerja selama 1115 tahun dengan pendapatan rata-rata per bulan sebesar Rp.500.000-Rp.999.999.

Dapat dikatakan keberadaan pramuwisata lokal perempuan di daya tarik wisata Alas Kedaton mengalami penurunan dari segi jumlah pramuwisata lokal, yang awalnya pramuwisata lokal di daya tarik wisata Alas Kedaton berjumlah 202 orang yang terdiri atas laki-laki dan perempuan, namun kini yang menggeluti profesi sebagai pramuwisata lokal di daya tarik wisata Alas Kedaton adalah kaum perempuan, berjumlah 80 orang pramuwisata lokal perempuan. Hal ini disebabkan karena satu orang pramuwisata lokal perempuan memegang 2 hingga 3 nomor antrean sekaligus dan dikarenakan penurunan tingkat kunjungan wisatawan ke daya tarik wisata Alas Kedaton. Selain itu, salah satu penyebab berkurangnya jumlah pramuwisata lokal perempuan adalah karena tidak menentunya penghasilan yang didapat. Penghasilan yang didapat oleh pramuwisata lokal hanya berasal dari $20 \%$ keuntungan penjualan cinderamata di artshop dan penjualan foto wisatawan bersama kelelawar.Jika wisatawan yang berkunjung ke daya tarik wisata Alas Kedaton berkurang, terlebih dengan berkurangnya minat belanja wisatawan, maka berkurang pula penghasilan yang diperoleh pramuwisata lokal perempuan.

Terkait mengenai motivasi pramuwisata lokal perempuan bekerja sebagai pramuwisata lokal di daya tarik wisata Alas Kedaton adalah untuk memenuhi beberapa kebutuhan yakni physiological needs dengan bentuk motivasi berupa pemenuhan kebutuhan sehari-hari (makan, minum, pakaian, dll) melalui penghasilan yang didapat sebagai pramuwisata lokal perempuan, safety and security needs dengan bentuk motivasi berupa rasa aman dari kecelakaan digigit kera serta rasa nyaman bekerja sebagai pramuwisata lokal perempuan, affiliation or acceptance needs dengan bentuk motivasi berupa hubungan dengan sesama pramuwisata lokal perempuan yang terjalin dengan baik, esteem or status needs dengan bentuk motivasi berupa penghargaan dari diri 
sendiri dan penghargaan dari orang lain (pengurus Kelompok Pedagang Alas Kedaton dan wisatawan), self actualization dengan bentuk motivasi berupa mengaktualisasikan potensi yang dimiliki yakni potensi berbahasa inggris serta pengetahuan tentang DTW Alas Kedaton. Rata-rata tanggapan pramuwisata lokal perempuan mengenai indikator physiological needs, safety and security needs, affiliation or acceptance needs, esteem or status needs, dan self actualization termasuk dalam kategori sangat setuju dan setuju. Hal ini menunjukkan bahwa kelima kebutuhan tersebut mampu terpenuhi dengan bekerja sebagai pramuwisata lokal perempuan di daya tarik wisata Alas Kedaton. Namun, motivasi yang paling besar yakni motivasi pemenuhan kebutuhan afiliasi atau affiliation or acceptance needs sejumlah 4,333 dengan kategori sangat setuju. Data ini menunjukkan bahwa motivasi pramuwisata lokal perempuan di daya tarik wisata Alas Kedaton cenderung untuk memenuhi kebutuhan sosial disamping motivasi-motivasi lainnya yang juga menjadi alasan mereka bekerja sebagai pramuwisata lokal perempuan. Hal ini dikarenakan hubungan antarsesama pramuwisata lokal perempuan di daya tarik wisata Alas Kedaton terjalin dengan baik, sehingga menjadi motivasi utama mereka tetap bertahan untuk menggeluti ptofesi sebagai pramuwisata lokal perempuan di daya tarik wisata Alas Kedaton.

\section{SIMPULAN DAN SARAN Simpulan}

1. Eksistensi pramuwisata lokal perempuan di daya tarik wisata Alas Kedaton berawal dari sejarah terbentuknya pramuwisata lokal perempuan hingga keberadaan pramuwisata lokal perempuan di daya tarik wisata Alas Kedaton sampai saat ini, meski terjadi penurunan jumlah pramuwisata lokal perempuan, namun dapat dikatakan masih eksis dalam hal melakukan aktivitas pemanduan wisatawan yang berkunjung ke daya tarik wisata Alas Kedaton sampai saat ini.

2. Motivasi pramuwisata lokal perempuan bekerja sebagai pramuwisata lokal di daya tarik wisata Alas Kedaton antara lain untuk memenuhi kebutuhan fisiologis, kebutuhan akan rasa aman, kebutuhan akan afiliasi atau rasa diterima oleh orang lain, kebutuhan akan penghargaan, dan kebutuhan aktualisasi diri. Sebagian besar jawaban mereka termasuk dalam kategori sangat setuju dan setuju. Adapun motivasi yang mendominasi dengan rata-rata skor terbesar yakni pada pemenuhan afiliasi atau affiliation or acceptance needs sejumlah 4,333.

\section{Saran}

1. Perlu adanya kerja sama antara pihak pengelola DTW Alas Kedaton dan pengurus Kelompok Pedagang Alas Kedaton dengan akademisi, pemerintah khususnya Dinas Pariwisata untuk memberikan pelatihan-pelatihan bahasa asing seperti bahasa inggris ataupun bahasa asing lainnya secara berkelanjutan untuk meningkatkan kemampuan berbahasa asing pramuwisata lokal perempuan yang ada di daya tarik wisata Alas Kedaton

2. Perlu adanya kerja sama untuk lebih mempromosikan daya tarik wisata Alas Kedaton agar tingkat kunjungan wisatawan lebih meningkat.

\section{DAFTAR PUSTAKA}

Anonim. 2016. Data Objek Wisata di Bali. http://www.disparda.baliprov.go.id/.

Diakses tanggal 19 Mei 2016

Hasibuan, Malayu S.P. 2015. Manajemen Dasar, Pengertian, Dan Masalah. Jakarta : PT. Bumi Aksara, Edisi Revisi.

Kusuma Negara, I Made. 2012. Potensi Ikan Air Tawar di Danau Batur Sebagai Pengembangan Wisata Alternatif. Analisis Pariwisata Vol.12 No.1 Th.2012.

Pardiana, Agus Yudi. 2015. Persepsi Wisatawan Domestik Terhadap Eksistensi Pekerja Fotografer di Daya Tarik Wisata Tanah Lot. Skripsi. Denpasar : Universitas Udayana.

Sugiyono. 2015. Metode Penelitian Manajemen. Cetakan Keempat. Bandung : Alfabeta. 